\title{
The Relationship between Destination Image, Food Image, and Revisiting Pattaya, Thailand
}

\author{
Sarunya Lertputtarak \\ Graduate School of Commerce, Burapha University \\ 169 Longhard Bangsaen Road, A.Muang, Chonburi, 20131, Thailand \\ E-mail: sarunya_L@hotmail.com
}

Received: November 20, 2011

Accepted: February 8, 2012

Published: March 1, 2012

doi:10.5539/ijbm.v7n5p111

URL: http://dx.doi.org/10.5539/ijbm.v7n5p111

\begin{abstract}
Destination image and food image are the essences of tourists' destination selections. The purposes of this research were to study tourists' perception toward destination image and Thai food image as well as study the relationship between those two variables and the tourists' intention to revisit. The research was conducted in Pattaya, Thailand. A questionnaire was used to survey 476 foreign visitors by a convenience sampling method. The results demonstrated that the respondents perceived the Pattaya image as; exciting nightlife and entertainment, communicative people, attractive tourist sightseeing and activities. Respondents perceived the Thai food image as; a good cultural experience, unique serving style, delicious, nourishing food, and exotic cooking methods, respectively. In addition, the results indicated that destination image and image of Thai food had a positive relationship with tourists' intention to revisit.
\end{abstract}

Keywords: Destination image, Food image, Intention to revisit, Thailand

\section{Introduction}

Tourist destination is a tourist product and service providing a holistic experience and cultural background (Funchs \& Weiermair, 2003). Destination managers should enhance attractiveness and its development positioning. One of the crucial elements of successful destination marketing is to create tourist satisfaction, which influences the choice of destination and the decision to revisit (Yoon \& Uysal, 2005).

Thailand is one of the most attractive tourist destinations. There were $8,835,294$ tourists who visited Thailand in 2010 and in 2011, only half a year from January to July, there were 11,178,275 tourists. In 2011, visitors from East Asia were in the majority with with 5,936,796 tourists, Europe with 3,014,207 tourists, South Asia with 701,685 tourists, America with 567,733 tourists, Oceania with 506,147 tourists, Middle East with 371,847 tourists, and Africa with 79,590 tourists (Department of Tourism, 2011).

Pattaya is one of the most important, not to be missed, destinations in Thailand. In 2010, there were 5,359,669 foreign tourists who visited Pattaya, while in 2009 there were 2,716,938 tourists. This meant that in 2010, $60.66 \%$ of tourists who came to Thailand also visited Pattaya (Department of Tourism, 2011).

Pattaya has many interesting activities. Besides beach and shopping activities, now the Thai government also promotes the country as 'a kitchen of the world'. A proverbial saying of the Thais is "In water there are fish, in the field there is rice." Thailand is an agricultural country and because of the suitable climate conditions Thailand can produce agricultural products all year round and has a reputation in being known for its food production and recognized as an important food exporting country. Furthermore, many varieties of Thai fruit continue to attract personal interests from many countries around the world. Thai food is an attractive delicacy, and the exquisiteness of the presentation combined with a high nutritional value with a distinct, delicious, unique taste which can make a strong impression as an exotic art of cooking.

As a country's food is governed by environmental factors and influenced by social, cultural, and religious backgrounds (McIntost, 1995), and every year many tourists who come to Thailand enjoy eating Thai food. Thai food is a blend of both Eastern and Western food, combined with some Buddhist principles that exist in the country. 
With regards to the application of tourism, the role of food could be to enhance the marketing of a destination. Different types of foods are consumed and connected to a particular location and can be the way to promote and market a destination. In this research, the researcher examines the roles of destination image and food toward an intention to a return by tourists who visit Pattaya. The benefits of this study will enhance marketers' perspective as to how to use food and destination image to encourage tourists to visit Thailand again and again.

\section{Literature Review}

\subsection{Destination image}

Several researchers have defined 'destination image' with different meanings. Hunt (1975) defined 'destination image' as visitors' perceptions about a destination. Some researchers defined 'destination image' based on cognitive aspects as belief and affective aspects as feeling (Baloglu \& MaCleary, 1999; Byon \& Zhang, 2010). Strong 'destination image' positioning can differentiate a destination from competitors to get into the visitors' mind (Mykletun, Crotts, \& Mykletun, 2001; Uysal, Chen, \& Williams, 2000). 'Destination image' should be context-specific as each place has its own unique characteristics.

Baloglu and McClearly (1999) categorized 'destination image' into three main factors: cognitive factors as the estimation process for tourism site selection, affective factors as belief and attitudes of the target destination, and conative factors as the final choice of one's destination, it is behavior image based on overt actions that visitors exhibit in relation to the image object (Gartner, 1993). Chalip, Green, \& Hill (2003) studied the effect of destination advertising and sports media by asking participants in the USA and New Zealand to rate the image of Australia's Gold Coast by a developed 40 items 'destination image' scale based on 9 cognitive factors: developed environment, natural environment, value, sightseeing opportunities, risk, novelty, climate, convenience, and family environment. While Obenour, Lengfelder, \& Groves (2005) purposed their research to assess the image of a newly developed nature-based tourist destination and investigate the influence of distance on the image of the destination by an internet survey of 610 respondents, Obenor et al. (2005) developed a 28 items scale with 6 image factors such as; priority, attractiveness for overnights, resources, facilities, peripheral attractiveness, and reputation. Hui and Wan (2003) studied tourists' image toward Singapore using 8 cognitive image dimensions, consisting of; leisure and tourist amenities, shopping and food paradise, local residents and nightlife, political stability, adventure and weather, culture, cleanliness, and personal safety and convenience.

'Destination image' positively influenced tourism behavioral intentions, especially the willingness to revisit (Castro, Armario, \& Ruiz (2007); Chi \& Qu, 2008). Bigne, Sanchez, \& Sanjez (2001) investigated the interrelationships among 'destination image', perceived quality, satisfaction, intention to return, and willingness to recommend to others in the context of resort visitors. They found that 'destination image' had a direct effect on the intention to return and a willingness to recommend to others.

\subsection{Food in tourism and Food image}

Eating is one of the physiological needs of a human being. Food and beverage expenditure amounts to one-third of overall tourist expenditures (Meler \& Cerovic, 2003). Australian and Canadian culinary tourism generated $\$ 7.2$ billion by 2010 (Pomero, 2005). A survey by Bangkok University Research Center showed that Thai food, which is diverse in appearance, aroma, color, and taste, is an aspect of Thailand which is most attractive to foreign visitors. International visitors, at 63.3 percent, are attracted primarily by Thai food (The Government Pubic Relation Department, 2011).

Food tourism is defined by Hall and Mitchell (2005, p.74: cited in Tikkanen (2007, p.725) as "a visitation to primary and secondary food producers, food festivals, restaurants and specific locations for which food tasting and/or experiencing the attributes of specialist food production regions is the primary motivating factor for travel." Food can be a tourist attraction (Hjalager \& Richards, 2002). Food is an attraction, is a product component, is an experience, and is a cultural phenomenon (Tikkanen, 2007).

According to the National Restaurant Association (NRA), more than six out of ten (63 percent) leisure travelers and 85 percent of culinary travelers enjoy trying new restaurants most nights during trips ( NRA, 2007: cited in Stewart, Bramble, \& Ziraldo, 2008, p.304). Dining habits help tourists understand differences between their own culture and a destination culture (Hegarty \& O’Mahoney, 2001). Reynolds (1993) studied that food and drink of a group of people can help them to understand the social and economic lifestyle of a destination or a country. Travelers have always searched for something that is different and authentic. For example, lobster in Maine is been well known for its popularity and also has become a regional icon. New Zealand green mussels are very tender and sweet in flavor unlike other mussels from other countries. Japanese food has unique types of food with a serving style. Rimmington and Yuskel (1998) found that the majority of travelers revisited Turkey for its 
cuisine, and food was the fourth factor that would contribute to travelers overall satisfaction (Hu and Ritchie, 1993).

When tourists traveled to different destinations they were not familiar with, they generally worried about climate, accommodation, health risks, and especially food and beverage that "There would be nothing to eat there" (Cohen \& Avleli, 2004). Beardsworth and Keil (1997) found that nutrient was not only a function of eating, but also introduces the experience of food tasting. Moreover, local eating habits and table manners can affect the perception of tourists towards a destination (Cohen \& Avleli, 2004).

The expectations and acceptable standards for food and service quality provided by restaurant staff are an important factor of concern. The provision of service providers to be reliable and responsive can enhance a destination's competitive advantage as a marketing tool (Dwyer, 2003). A poor quality and service failure can impact negatively on health, disrupting trips, and tarnishing destination reputations (Pendergast, 2006). In addition, Kim et al. (2011) found the direct relationship between amount of money spent on food at an event and satisfaction and an intention to revisit.

It can be concluded that the main factors that we should be concerned with when measuring food image are food itself and place where food is sold which can demonstrate the uniqueness of food and food serving style with value for money.

In this study, the researcher focused on studying Thai food image. Thai food has become more widely known and it has also gained greater recognition internationally. It is a harmonious combination of tastes and medicinal qualities, as the ingredients are mainly vegetables and herbs, such as lemon grass, galangal, basil, and garlic. The special quality of Thai food is its ability to reflect three key values: nutritional, cultural, and medicinal cooking with fresh ingredients, a well-trained natural talent in cooking methods, presentation techniques, and the generous use of herbs and spices. Thai food is appealing to the eye, nose, and palate as Thai chefs pay attention to detail at each and every step of food preparation. Thai cookery can be defined as an art and an essential part of the nation's cultural heritage passed on from generation to generation (The Government Pubic Relation Department, 2011). Today Thai restaurants and Thai food can be found in almost all parts of the world, especially in major cities such as Pattaya.

Food quality can be one of the factors which drives tourists to have an intention to return to a destination. Kim et al. (2011) found that food tourists' intention to revisit could be explained and predicted by the perceived value of food and satisfaction. The results of their study are also supported by research papers conducted by Kim, Goh and Yuan (2010) and Kim et al. (2010).

\subsection{Conceptual Framework}

Figure 1 demonstrates conceptual framework of this study

Insert Figure 1 here

\section{Methodology}

This study is a descriptive research using a questionnaire as the method for collecting data at Pattaya, Thailand. 500 foreign tourists able to understand English were invited to fill out the questionnaire by using convenience sampling due to time and budget restrictions. The samples were collected at Pattaya's Jomtien Beach. The complete number of questionnaires which could be used for data analysis were 476 questionnaires. With regard to the sample size, it is normally based on the statistical requirements of the researcher. Hair (2005) recommended a sample size should be at least five times higher than the number of variables for factor analysis. A sample size between 200 and 400 is normally recommended and accepted as a critical sample size.

For this study, as Pattaya never had any researchers to develop an image measurement scale before, the researcher developed a scale based on both cognitive and affective aspects as well as an interview with which tourism experts ( 3 academicians) and destination managers ( 2 destination managers) viewed the characteristics of Pattaya's image in order to improve the questions to enhance clarity, readability and content validity.

There were 8 items to measure destination image: opportunity for adventure, exciting nightlife and entertainment, relaxing, pleasant, friendly /trustworthy people, communicative people, safety, and attractive tourist sightseeing and activities.

The Thai food image scale measured 19 items: a well-known/popular cuisine in the world, variety of food, food gives a culture experience, local food ingredients, tastiness, nourishing food, unique food, food hygiene, Thai herbs good for health, taste of Thai fruits, attractive food presentation, deliciousness, freshness, exotic cooking 
methods, variety of attractive restaurant types, unique serving style of restaurant staff, learning local eating habits and table manners, environment and unique style of decoration, and reasonable price/value for money.

The questionnaire was written only in the English language. The questionnaire consisted of 4 parts:

The first part was regarding personal information using a nominal and ordinal scale asking about tourists' gender, age, marital status, level of education, occupation, home country, how many days to stay in Pattaya, repeat visitor/ first time visitor.

The second part was a set of questions about tourists' perception toward the destination image. The respondents were asked to respond to a statement indicating a measure on a five-point Likert scale (1-low to 5-high).

The third part was a set of questions about tourists' perception toward Thai food image. The respondents were asked to respond to a statement indicating a measure on a five-point Likert scale (1-low to 5-high).

The forth part was a set of questions about tourists' intention to revisit. The respondents were asked to respond to the questions indicating a measure on a five-point Likert scale (1-strongly disagree to 5 -strongly agree). The questions were "If you have a chance, would you visit Pattaya again?" And "If you plan to travel to South-east Asia, is Pattaya the first choice to revisit?"

The pilot survey with 35 respondents helped the researcher to formulate the final questionnaire by rephrasing vague questions, the results showed that destination image had a Cronbach alpha $=0.8126$, image of Thai food $=$ 0.8470 , and intention to revisit $=0.8049$.

Data was analyzed by using SPSS software provided by the Graduate School of Commerce, Burapha University. Data analysis was divided into three sections using descriptive and inferential statistics. The first section used descriptive statistics to explain tourists' personal information, their perception toward destination image, image of Thai food, and intention to revisit by calculating frequency and percentage.

The second section used exploratory factor analysis to identify the underlying factors of Thai food image attributes. The categories of image from factor analysis were used to explain each variable set and not to predict a dependent variable. Principle components and varimax rotation procedures were used to identify the factor dimensions. The benefits of using this method is that it allows minimizing the number of variables that have a high loading on the factor in order to improve the interpretability of the factors and maintains the factors that are not correlated with each other. The latent root criterion of 1.0 was used for factor extraction and factor loading of .30 were significant and used for interpretation of results (Tarek, 2008). Finally in the third section, multiple linear regression analysis was applied to determine the relationship between independent and dependent variables.

\section{Results}

\subsection{Profiles of respondents}

The study found that with 476 respondents, they were male $52.3 \%$ and female $47.7 \%$. the majority of them were 25-34 years old $(29.2 \%)$, single $(47.9 \%)$, education level Bachelor degree $(47.3 \%)$, and work in private organizations (29.1\%). The majority of them were Europeans (29.2\%), planned to stay in Pataya for 1 week to 1 month (35.3\%) and they were revisited tourists $(67.8 \%)$. The results of personal data of tourists are shown in Table 1.

Table 1 shows respondents' information

\section{Insert Table 1 here}

\subsection{Descriptive analysis of variables}

The overall mean of the destination image was 3.82 (high), image of Thai food was 3.59 (high), and the intention to revisit was 3.88 (high).

By examining each component of the destination image, the results showed the following; opportunity for adventure $(\overline{\mathrm{X}}=3.82$ (high)), exciting nightlife and entertainment $(\overline{\mathrm{X}}=3.97$ (high)), relaxing $(\overline{\mathrm{X}}=3.65$ (high)), pleasant $(\overline{\mathrm{X}}=3.68(\mathrm{high}))$, friendly and trustworthy people $(\overline{\mathrm{X}}=3.67$ (high) $)$, communicative people $(\overline{\mathrm{X}}=3.92$ (high)), safety $(\overline{\mathrm{X}}=3.84(\mathrm{high}))$, and attractive tourist sightseeing and activities $(\overline{\mathrm{X}}=3.87$ (high)).

In examining each component of the 'Image of Thai food', all of items were at high level. The results are shown in Table 2.

Table 2 shows mean of image of Thai food 
By using Factor analysis to classify each component of the 'Image of Thai food', the results showed that two main factors were apparent. The first factor was labeled "Food Image", whereas the second one was named "Thai Restaurant Image".

Table 3 shows factor analysis of image of Thai food.

Insert Table 3 here

\subsection{Results of hypothesis testing}

A Simple Linear Regression and multiple Linear Regression was used to solve hypothesis one and two. The results were that:

Hypothesis 1: Pattaya destination image has a positive relationship with an intention to revisit. The $\mathrm{R}$ square was .374 , which means that $37.4 \%$ of the total variance in the dependent variable could be explained by the independent variables in the model. The final regression equation model is illustrated as follows:

$$
\text { Intention to revisit }=0.612 \text { (destination image) }+\mathrm{e}
$$

Hypothesis 2: The Image of Thai food has a positive relationship with an intention to revisit. The $\mathrm{R}$ square was .154 , which means that $15.4 \%$ of the total variance in the dependent variable could be explained by the independent variables in the model. The final regression equation model is illustrated as follows:

$$
\text { Intention to revisit }=0.120(\text { food image })+0.234 \text { (Thai restaurant image })+e
$$

\section{Discussion}

It is essential for destination managers to understand the importance of how to set positioning strategy for a tourist destination. The move away from mass-standardization forces destination managers to search for better alternative marketing strategies that can identify and exploit new opportunities that are attractive, economical, and sustainable (Ibrahim \& Gill, 2005). To understand how tourists perceived the destination image and then design activities to serve need and satisfy the target market can bring about a competitive advantage. Etchner \& Ritchie (1993) stated that image of destination should be attributed-based components that can identify the relative strengths and weakness of the destination and contribute to a potential niche market for developing destination positioning. According to Botha (1999) image creation should be based on a measurement of what already exists in the tourists' minds, instead of asking what you are, the destination managers should ask what perception already exists in the mind of a prospective tourist. The result of this study stated that tourists perceived image of Pattaya is at a high level. Pattaya had an exciting nightlife and entertainment was in the first rank. Most of the nightlife action geared towards tourists is found in South Pattaya, with the densest concentration of bars, and discos known as Walking Street. However, the tourists can spend time with other activities at night such as the cultural extravaganza 'Alangkarn' in Pattaya, which offers fun-for-all entertainment. Employing a state-of-the-art light and sound system, the show is guaranteed to captivate audiences of all ages with a lavish production performed by professionally trained artists, or enjoy the world-famous Alcazar Cabaret Show- one of Thailand's foremost lady-boy cabarets. The second rank was ease to communicate. A main occupation of Thai people in Pattaya was to serve tourists, they sold products and service to tourists thus they can speak and use English or another language as well. The third rank was Pattaya had attractive tourist sightseeing and activities, especially beach activities such as banana boats, jet skis, and a Water Park. Pattaya also had other activities such as go-karting, golf packages, paintball, tower descent, etc. Moreover, Pattaya is also good for shopping. The forth rank regards safety. Although Thai politics was not stable, Pattaya was still safe in the tourists' mind. The following rank was that Pattaya provided an opportunity for adventure, pleasant atmosphere, where people were friendly and trustworthy, and lastly Pattaya was a place for relaxing.

In solving hypothesis one it was found that the destination image had a positive relationship with an intention to return. The result of this study was supported by Baloglu and McClearly (1999) who found that the destination image positively influenced a tourist's first visit and also influenced revisit intentions among existing travelers (Bigne et al., 2001). Kozak (2001) found a relationship between overall satisfaction and the intention to make a repeat visit.

This research also found that the image of Thai food had a positive relationship with an intention to revisit. Physiological need of food was one of the motivations for food tourism. Tourists and the tourism industry around the world share an interest in food. Food can be seen as a tourist attraction to the place that they visited (Hjalager \& Richards, 2002). The image of Thai food in the perception of tourists was at a high level. Examining each component from first to tenth rank, tourists ranked Thai food giving a culture experience as first, then 
restaurants had a unique of serving style of staff, deliciousness, nourishing food, exotic cooking methods, Thai's herb is good for health, food hygiene, local food ingredient, freshness, unique food, tastiness, and reasonable price/value for money, respectively. Therefore, developing a reputation of Thai food and service quality of Thai restaurants should be a concern for destination managers. Pendergast (2006) found that poor quality and service failure can impact negatively on health, disrupting trips and finally tarnishing destination reputation. Increase of tourists' satisfaction was an excellent predictors of repurchase intentions (Choi \& Chu, 2001), and finally bringing revenue to a destination (Baker \& Cromption, 2000).

\section{Conclusion}

\subsection{Conclusions and recommendation}

In the competitive marketplace of tourism, an effective marketing strategy can attract new visitors while maintaining revisit travelers. From the previous studies, researchers found that increasing tourists' satisfaction had a positive effect with an intention to return. Bigne, Sanchez, \& Sanjez (2001) found the interrelationships among 'destination image', perceived quality, satisfaction, intention to return, and willingness to recommend to others in the context of resort visitors.

In order to make tourists feel satisfaction, destination marketers should be concerned with important factors that can motivate tourists. This study found that the overall Pattaya destination image, including opportunity for adventure, exciting nightlife and entertainment, relaxing, pleasant, friendly and trustworthy people, communicative people, safety, and attractive tourist sightseeing and activities, had a positive relationship with an intention to return.

Thai food image had a positive relationship with an intention to return. The food image divided into two group: food image and restaurant image. The food image were a well-known/popular cuisine in the world, variety of food, a culture experience, local food ingredients, tastiness, nourishing food, unique food, food hygiene, Thai herb is good for health, taste of Thai fruits, attractive food presentation, deliciousness, freshness, and exotic cooking methods. While Thai restaurant image were Variety of attractive restaurant types, Unique serving style of restaurant staff, Learning local eating habits and table manners, Environment and unique style of decoration, and Reasonable price/value for money.

Therefore, increase of tourists' satisfaction was an excellent predictors of repurchase intentions, and finally bringing revenue to a destination. The recommendations below can assist destination managers to develop their strategies. Therefore the recommendations for this study are:

As Pattaya is famous for nightlife and entertainment, there should be a positioning of Pattaya as a destination for night time entertainment by adding more activities instead of focusing on beer bars or Go-Go bars. Tourists can learn Thai culture when visiting Pattaya by watching cultural or Thai traditional shows. Moreover, Thai food and Thai restaurants can be an outstanding marketing strategy to encourage tourists to be impressed with Thai culture.

Pattaya can reposition or advertise day-time activities to catch a niche market. Marketers should provide more information about beach or sport activities. Sport events to help promote a destination's image so tourists could perceive that Pattaya had attractive tourist sightseeing and activities. The local government, event marketers, and destination marketers as well as residents should work together to improve and to promote the event quality to maximize effects of hosting an international sport and activity events.

Tourists' perceived image of Pattaya as a well-known/popular cuisine in the world is in the lowest rank. Hence, destination managers should provide more advertizing regarding Thai Food so as to educate tourists about how delicious the food is, how healthy the food is, and that eating Thai food is another way to learn about Thai culture.

Thai people were well-known for their polite manner and being friendly. Restaurant owners could position their restaurants as a place to learn Thai culture, serving customers with Thai polite manners, treating customers like they were at home and with such a warm welcome would create tourists' satisfaction toward places. However, the restaurant owners should realize that different cultures can make customers be worried about food and how to eat food when they face unfamiliar foodstuffs and dishes. Therefore, restaurant owners should train their staff how to teach or recommend tourists about how to eat in a Thai style. Western individualism found expression in the separate apportioning of food to each other, and the use of personal eating utensils. Sensitive Westerners may feel reluctant to share food with other people. Thus, when Western tourists were dinning out in Thai restaurants, they tended to use separate utensils to dish out the food.. 
Menus should give more details about ingredients and the benefits in eating Thai's herbs for health. With some dishes like a seafood menu, tourists may refuse to choose fish or any live animals which may be on display. But in Thai restaurants, the display is intended to demonstrate the variety, quality, and freshness of the food. It is just simple manners for local customers to point to the creature of choice, which was promptly killed, cleaned, and cooked to order. But the prompt preparation should not be done in front of the customers. The restaurant owners should understand the differences between the eating cultures of their customers.

Restaurant decoration was one of the marketing strategies to create an impression with customers. Serving in Thai style, listening to Thai musical music and watching a Thai dance can differentiate Thai restaurants from other countries' restaurants.

According to the results of the study, variety of food in menu was not in the top ten rank of Thai food image, therefore rather than preparing a rich and diverse local cuisine for tourists, the business owners could guide tourists regarding food that they are familiar such as Pat Thai, Khao Pat, Tom Yam, Green or Red curry, where those menus were similar to menus in Thai restaurants in the tourists' home countries.

\subsection{Recommendations for Further Study}

6.2.1 Researchers should compare travelers from different countries because some tourists were more selective in terms of food choice. Moreover, there could be comparisons between travelers of one country by examining differences in personal characteristics such as tourists with; different ages, family backgrounds, life-styles, and preferences may have different perspectives in terms of destination image and food choice.

6.2.2 Researchers should evaluate travelers' perception of food and destination by using qualitative research in order to understand an in-depth requirement of them. Nevertheless, researchers should conduct a focus on more than one or two groups because more focus groups could provide more insightful ideas.

6.2.3 Researchers could study destination image in other parts of Thailand or in other countries. The measurement of destination image could be developed depending on the attraction of each destination.

\section{Limitations}

7.1 The data collection was collected by convenience sampling and the results cannot be generalized to the whole population. In addition, the majority of respondents in this study were from Asia and Europe, which could be overrepresented in the data set.

7.2 The data was collected in Thailand, tourists may have a positive perception about destination before they came to Thailand that encouraged them to make a decision to visit this country especially Pattaya. If data was collected in other countries, the results may be different from this study. The degree of familiarity with the country was questionable.

7.3 The findings were limited to only Pattaya. Thai food image should be studied in other parts of Thailand as well in order to find the differences between different places.

\section{References}

Baker, D.A., \& Crompton, J.L. (2000). Quality, satisfaction and behavioral variables. Annals of Tourism Research, 27(3), 785-804. http://dx.doi.org/10.1016/S0160-7383(99)00108-5

Baloglu, S., \& McCleary, K.W. (1999). A model of destination image formation. Annuals of Tourism Research, 35, 868-897. http://dx.doi.org/10.1016/S0160-7383(99)00030-4

Beardsworth, A, \& Keil, T. (1997). Sociology of the Menu. London: Routledge.

Bigne, E.J., \& Sanchez, I.M., \& Sanjez, J. (2001). Tourism image, evaluation variables and after-purchase behavior: inter-relationship. Tourism $\quad$ Management, $\quad 22, \quad$ 607-616. http://dx.doi.org/10.1016/S0261-5177(01)00035-8

Botha, C., Cromption, J., \& Ki, S. (1999). Developing a revised competitive strategy for sun/lost city, South Africa. Journal of Travel Research, 37(2), 341-352.

Byon, K.K., \& Zhang, J.J. (2010). Development of a scale measuring destination image. Marketing Intelligence \& Planning, 28(4), 508-532. http://dx.doi.org/10.1177/004728759903700404

Castro, C.B., Armario, E.M., \& Ruiz, D.M. (2007). The influence of market heterogeneity on the relationship between a destination's image and tourists' future behavior. Tourism Management, 28, 175-187. http://dx.doi.org/10.1016/j.tourman.2005.11.013 
Chalip, L., Green, B.C., \& Hill, B. (2003). Effects of sport event media on destination image and intention to visit. Journal of Sport Management, 17, 214-234.

Chi, C., \& Qu, H. (2008). Examining the structure relationships of destination image and destination loyalty: an integrated approach. Tourism Management, 29. 624-636. http://dx.doi.org/10.1016/j.tourman.2007.06.007

Choi, T.Y., \& Chu, R. (2001). Deterninants of hotel guests' satisfaction and repeat patronage in the Hong Kong hotel industry. International Journal of Hospitality Management, 20(3), 277-297. http://dx.doi.org/10.1016/S0278-4319(01)00006-8

Cohen, E., \& Avieli, N. (2004). Food in tourism: attraction and impediment. Annals of Tourism Research, 31(4), 755-778. http://dx.doi.org/10.1016/j.annals.2004.02.003

Department of Tourism. (2010). Tourists arrival in Thailand. (August 18, 2011) [Online] Available: http://www.tourism.go.th/2010/upload/filecenter/file/stat_2553/Update\%20on\%203Aug\%2054/East.pdf

Dwyer, K. (2003). Destination competitiveness: determinants and indicators. Current Issues in Tourism, 6(5), 369-414. http://dx.doi.org/10.1080/13683500308667962

Etchner, C., \& Ritchie, B. (1991). The meaning and measurement of a destination image. Journal of Tourism Studies, 2(2), 2-12.

Fuchs, M., \& Weiermair, K. (2003). New perspective of satisfaction research in tourism destinations. Tourism Review, 58(3), 6-14. http://dx.doi.org/10.1108/eb058411

Gartner, W.C. (1993). Image formation process. Journal of Travel \& Tourism Marketing, 2 (2/3), 191-215. http://dx.doi.org/10.1300/J073v02n02_12

Hair, J., Anderson, R., Tatham, R., \& Black, W. (2005). Multivariate Data Analysis (6 ${ }^{\text {th }}$ Ed.) New Jersey: Prentice Hall.

Hall, M., \& Mitchell, R. (2005). Gastronomic tourism: comparing food and wine tourism experiences, in Novelli, M. (Ed.), Niche Tourism, Comtemporary Issues, Trends and Cases, Elsevier, Barking.

Hegarty, J.A., \& O'Mahoney, G.B. (2001). Gastonomy: a phenomenon of cultural expressionism and an aesthetic for living. International Journal of Hospitality Management, 20(1), 3-13. http://dx.doi.org/10.1016/S0278-4319(00)00028-1

Hjalager, A., \& Richards, G. (Eds) (2002). Tourism and Gastronomy. London: Routledge.

Hu, Y., \& Ritchie, J.R.B. (1993). Measuring destination attractiveness: A contextual approach. Journal of Travel Research, 32(2), 25-34.

Hui, T.K., \& Wan, T.W.D. (2003). Singapore's image as a tourist destination. International Journal of Tourism Research, 5, 305-313. http://dx.doi.org/10.1002/jtr.437

Hunt, J.D. (1975). Image as a factor in tourism development. Journal of Travel Research, 13(3), 1-7. http://dx.doi.org/10.1177/004728757501300301

Ibrahim, E.E., \& Gill, J. (2005). A positioning strategy for a tourist destination, based on analysis of customers' perceptions and satisfactions. Marketing Intelligence \& Planning, 23(2), 172-188.

Kim Y.H., Kim, M., Goh, K.B., \& Antun, M.J. (2011). The role of money: the impact on food tourists' satisfaction and intention to revisit food events. Journal of Culinary Science \& Technology, 9(2), 85-98. http://dx.doi.org/10.1080/15428052.2011.580708

Kim, Y.H., Goh, B.K., \& Yuan, J. (2010). A development of a multi-dimensional scale for measuring the motivation factors of food tourists at a food event: what does motivate people to travel? Journal of Quality Assurance in Hospitality and Tourism, 11(1), 56-71. http://dx.doi.org/10.1080/15280080903520568

Kim, Y.H., Kim, M., Ruetzler, T., \& Taylor, J. (2010). An examination of festival attendee's behavior using SEM. International Journal of Event and Festival Management, 1(1), 86-95. http://dx.doi.org/10.1108/17852951011029324

Kozak, M. (2001). Repeaters' behavior at two distinct destinations. Annals of Tourism Research, 28(3), 784-807. http://dx.doi.org/10.1016/S0160-7383(00)00078-5

McIntosh, R. (1995). American food habits in historical perspective. Westport, CT: Praeger.

Meler, N., \& Cerovic, Z. (2003). Food marketing in the function of tourist product development. British Food Journal, 105(3), 175-192. http://dx.doi.org/10.1108/00070700310477121 
Mykletun, R.J., Crotts, J.C., \& Mykletun, A. (2001). Positioning an island destination in the peripheral area of the Baltics: a flexible approach to market segmentation. Tourism Management, 22(5), 493-500. http://dx.doi.org/10.1016/S0261-5177(01)00004-8

Obenour, W., Lengfelder, J., \& Groves, D. (2005). The development of a destination through the image assessment of six geographic markets. Journal of Vacation Marketing, 11, 107-119. http://dx.doi.org/10.1177/1356766705052569

Pendergast, D. (2006). Tourist gut reactions: food safety and hygiene issues, in Wilks, J., Pendergast, D., \& Leggat, P. (Eds). Tourism in Turbulent Times: towards Safe Experiences for Visitors, Amterdam: Elsevier, pp.143-154.

Pomero, P. (2005). Travelers explore new world of culinary tourism. Nation's Restaurant News, 39(26), 3-5.

Reynolds, P. (1993). Food and tourism: towards an understanding of sustainable culture. Journal of Sustainable Tourism, 1(1), 48-54. http://dx.doi.org/10.1080/09669589309514796

Rimmington, M., \& Yuskel, A. (1998). Tourist satisfaction and food service experience: results and implications of an empirical investigation. Anatolia, 9(1), 37-57. http://dx.doi.org/10.1080/13032917.1998.9686958

Stewart, J.W., Bramble, L., \& Ziraldo, D. (2008). Key challenges in wine and culinary tourism with practical recommendations. International Journal of Contemporary Hospitality Management, 20(3), 302-312. http://dx.doi.org/10.1108/09596110810866118

Tarek, S. (2008). Advances in Computer and Information Sciences and Engineering. USA: Spinger.

The Government Pubic Relation Department. (2011). Thai Food Cited as the Most Attractive to International Tourists. [Online] Available: http://thailand.prd.go.th/view_inside.php?id=5448 (August 24, 2011).

Tikkanen, I. (2007). Maslow's hierarchy and food tourism in Finland: five cases. British Food Journal, 109(9), 721-734.

Uysal, M., Chen, J., \& Williams, D. (2000). Increasing state market share through a regional positioning. Tourism Management. 21(1), 89-96. http://dx.doi.org/10.1016/S0261-5177(99)00082-5

Yoon, Y., \& Uysal, M. (2005). An examination of the effects of motivation and satisfaction on destination loyalty: a structural model. Tourism Management, 26, 45-56. http://dx.doi.org/10.1016/j.tourman.2003.08.016 
Table 1. Shows respondents' information

\begin{tabular}{|c|c|c|}
\hline Sample personal information & Frequency & Percentage \\
\hline $\begin{array}{l}\text { Gender } \\
\text { Male } \\
\text { Female }\end{array}$ & $\begin{array}{l}249 \\
227\end{array}$ & $\begin{array}{l}52.3 \\
47.7\end{array}$ \\
\hline $\begin{array}{l}\text { Age } \\
\text { Less than } 25 \text { years old } \\
25-34 \text { years old } \\
35-44 \text { years old } \\
45-54 \text { years old } \\
\text { More than } 55 \text { years old }\end{array}$ & $\begin{array}{c}87 \\
139 \\
93 \\
78 \\
79\end{array}$ & $\begin{array}{l}18.3 \\
29.2 \\
19.5 \\
16.4 \\
16.6\end{array}$ \\
\hline $\begin{array}{l}\text { Marital Status } \\
\text { Single } \\
\text { Married } \\
\text { Widow }\end{array}$ & $\begin{array}{c}228 \\
188 \\
60\end{array}$ & $\begin{array}{l}47.9 \\
39.5 \\
12.6\end{array}$ \\
\hline $\begin{array}{l}\text { Level of Education } \\
\text { Lower than a Bachelor } \\
\text { degree } \\
\text { Bachelor degree } \\
\text { Higher than a Bachelor } \\
\text { degree }\end{array}$ & $\begin{array}{l}148 \\
225 \\
103\end{array}$ & $\begin{array}{l}31.1 \\
47.3 \\
21.6\end{array}$ \\
\hline $\begin{array}{l}\text { Occupation } \\
\text { Government officer } \\
\text { Private organization } \\
\text { officer } \\
\text { Business owner } \\
\text { Student } \\
\text { Retirement/others }\end{array}$ & $\begin{array}{c}44 \\
138 \\
\\
120 \\
94 \\
80\end{array}$ & $\begin{array}{c}9.2 \\
29.1 \\
\\
25.2 \\
19.7 \\
16.8\end{array}$ \\
\hline $\begin{array}{l}\text { Home Region } \\
\text { Asia } \\
\text { Europe } \\
\text { North America } \\
\text { Oceania } \\
\text { South America } \\
\text { Africa } \\
\text { Middle east }\end{array}$ & $\begin{array}{c}119 \\
139 \\
93 \\
50 \\
20 \\
25 \\
30 \\
\end{array}$ & $\begin{array}{l}25.1 \\
29.2 \\
19.5 \\
10.5 \\
4.2 \\
5.2 \\
6.3 \\
\end{array}$ \\
\hline $\begin{array}{l}\text { Length of Stay in Pattaya } \\
\text { Less than one week } \\
\text { One week ( } 7 \text { days) } \\
\text { Between one week-one } \\
\text { Month } \\
\text { More than one month }\end{array}$ & $\begin{array}{c}75 \\
144 \\
168 \\
\\
89\end{array}$ & $\begin{array}{l}15.7 \\
30.3 \\
35.3 \\
18.7\end{array}$ \\
\hline $\begin{array}{l}\text { Revisit/First Time Visit } \\
\text { Revisit } \\
\text { First time visit }\end{array}$ & $\begin{array}{l}323 \\
153\end{array}$ & $\begin{array}{l}67.8 \\
32.2\end{array}$ \\
\hline
\end{tabular}


Table 2. Shows mean of image of Thai food

\begin{tabular}{|l|c|c|}
\hline \multicolumn{1}{|c|}{ Image of Thai food } & Mean & Level \\
\hline 1. A well-known/popular cuisine in the world & 3.53 & High \\
2. Variety of food & 3.69 & High \\
3. Food gives a culture experience & 4.59 & High \\
4. Local food ingredients & 4.16 & High \\
5. Tastiness & 4.00 & High \\
6. Nourishing food & 4.53 & High \\
7. Unique food & 4.09 & High \\
8. Food hygiene & 4.32 & High \\
9. Thai herb is good for health & 4.39 & High \\
10. Taste of Thai fruits & 3.83 & High \\
11. Attractive food presentation & 3.83 & High \\
12. Deliciousness & 4.53 & High \\
13. Freshness & 4.13 & High \\
14. Exotic cooking methods & 4.49 & High \\
15. Unique serving style of restaurant staff & 4.56 & High \\
16. Variety of restaurant types & 3.72 & High \\
17. Learning local eating habits and table manners & 3.59 & High \\
18. Environment and unique style of decoration & 3.63 & High \\
19. Reasonable price/value for money & 3.86 & High \\
\hline
\end{tabular}

Table 3. Shows factor analysis of image of Thai food

\begin{tabular}{|l|c|c|}
\hline \multicolumn{1}{|c|}{ Image of Thai food } & $\begin{array}{c}\text { Loading } \\
\text { Factor 1 }\end{array}$ & $\begin{array}{c}\text { Loading } \\
\text { Factor 2 }\end{array}$ \\
\hline Food image: & .839 & \\
1. A well-known/popular cuisine in the world & .831 & \\
2. Variety of food & .784 & \\
3. Food gives a culture experience & .719 & \\
4. Local food ingredients & .713 & \\
5. Tastiness & .670 & \\
6. Nourishing food & .642 & \\
7. Unique food & .613 & \\
8. Food hygiene & .594 & \\
9. Thai herb is good for health & .588 & \\
10. Taste of Thai fruits & .575 & \\
11. Attractive food presentation & .555 & \\
12. Deliciousness & .553 & \\
13. Freshness & .417 & \\
14. Exotic cooking methods & & \\
\hline Thai restaurant image: & & .804 \\
1. Variety of attractive restaurant types & & .714 \\
2. Unique serving style of restaurant staff & & .624 \\
3. Learning local eating habits and table manners & .361 \\
4. Environment and unique style of decoration & & .324 \\
5. Reasonable price/value for money & & \\
\hline
\end{tabular}




\section{Pattaya destination image}

1. Opportunity for adventure

2. Exciting nightlife and entertainment

3. Relaxing

4. Pleasant

5. Friendly /trustworthy people

6. Communicative people

7. Safety

8. Attractive tourist sightseeing and activities

\section{Image of Thai food}

1. A well-known/popular cuisine in the world

2. Variety of food

3. Variety of attractive restaurant types

4. Food gives a culture experience

5. Local food ingredients

6. Tastiness

7. Nourishing food

8. Unique food

9. Food hygiene

10. Thai herb is good for health

11. Taste of Thai fruits

12. Attractive food presentation

13. Deliciousness

14. Freshness

15. Exotic cooking methods

16. Unique serving style of restaurant staff

17. Learning local eating habits and table manners

18. Environment and unique style of decoration

19. Reasonable price/value for money

Figure 1. Conceptual framework 